\title{
Studi Deskriptif Kualitatif tentang Hambatan Komunikasi Fotografer dan Model dalam Proses Pemotretan
}

\author{
Wiki Angga Wiksana \\ Fakultas Ilmu Komunikasi, Universitas Islam Bandung, Jl.Taman Sari No.1 Bandung \\ E-mail: wikianggawiksana@gmail.com
}

\begin{abstract}
Abstrak. Setiap individu tidak lepas dari proses komunikasi dalam kehidupan sehari-hari. Begitupun halnya terjadi pada seorang fotografer. Fotografer tidak bisa lepas dari interaksi sosial atau biasa disebut human relation, baik dalam berkomunikasi dengan foto model, asisten, tim, dan lingkungan sekitarnya. Bidang fotografi yang paling sering terjadi interaksi di antara manusia adalah fotografi model, karena pada bidang ini objek fotonya adalah manusia. Dalam penelitian ini, penulis melihat adanya interaksi antara fotografer dan modelnya. Penelitian ini bertujuan mengungkapkan hambatan komunikasi antara fotografer dan model dalam proses pemotretan. Metode penelitian yang digunakan adalah pendekatan kualitatif dengan metode deskriptif. Dalam hal ini, teknik pengumpulan data tersebut dilakukan dengan wawancara mendalam, pengamatan, dan studi dokumentasi. Hasil penelitian tentang hambatan komunikasi dalam interaksi fotografer dan foto model dalam proses pembuatan karya foto terjadi secara bervariasi, mulai dari hambatan psikologis, hambatan semantik, dan hambatan pengetahuan. Pada prinsipnya, hambatan komunikasi inilah yang terjadi antara fotografer dan model dalam proses pemotretan.
\end{abstract}

Kata kunci: hambatan komunikasi, fotografer, model

Abstract. Every individual can not be separated from the communication process in everyday life. Likewise that happens to a photographer. Photographers can not be separated from social interactions or so-called human relationships, both in communicating with models, assistants, teams, and the surrounding environment. The most common field of photography among humans is the photographic model, because in this field, the object of the photograph is human. In this study, the author sees the interaction between the photographer and his model. This study is intended to see the interaction between photograpger and the model. The research method used is qualitative approach with descriptive method. In this case, the technique of completing the data is done with in-depth interviews, observations, and documentation studies. The results of research on communication barriers in the interaction of photographers and photo models in making story-making, ranging from psychological barriers, semantic barriers, and knowledge barriers. In principle, this communication barrier that occurs between the photographer and the model in the process of shooting.

Keywords: communication barrier, photographer, model 


\section{PENDAHULUAN}

Selayaknya kehidupan pada umumnya, seorang fotografer adalah manusia yang saling berhubungan sosial di mana pun berada. Tidak bisa dipungkiri bahwa seorang fotografer tidak bisa lepas dari interaksi sosial atau biasa disebut human relations, dalam setiap aktivitasnya sebagai seorang fotografer selalu berkomunikasi dengan foto model, asisten, tim, dan lingkungan sekitarnya.

Bidang fotografi yang paling sering terjadi interaksi di antara manusia adalah fotografi dalam bidang foto model, karena pada bidang foto ini objek fotonya adalah manusia. Dalam hal ini, akan terdapat minimal dua orang yang berinteraksi, yaitu antara fotografer dan modelnya, dan interaksi itu terus berlangsung selama proses pemotretan berlangsung.

Seorang fotografer tentunya akan selalu berkomunikasi dengan para model. Dalam hal ini, mereka akan berusaha untuk membuat suasana interaksi diantara mereka menjadi lebih nyaman. Saat berinteraksi dengan mereka, seorang fotografer bisa memerhatikan dan menilai bahasa tubuh mereka, sehingga fotografer dapat lebih mudah menyampaikan ide sudut pandang dan pose yang diinginkan kepada model fotonya. Hasilnya adalah karya foto yang sesuai dengan konsep yang diinginkan fotografer.

Dalam penelitian ini, penulis melihat adanya hambatan komunikasi dalam interaksi fotografer dan model. Pada saat sekarang ini, dunia fotografi sangat diminati oleh banyak orang yang ada di seluruh penjuru dunia ini. Dengan memiliki kemampuan komunikasi yang baik untuk menyampaikan maksud dan tujuan dari konsep fotonya, fotografer tentunya memiliki keuntungan dengan mendapatkan hasil karya foto yang sesuai dengan konsep fotografinya dan juga aktivitasnya tidak mengganggu orangorang di sekitarnya dan mereka pun akan lebih senang membantu dalam proses pemotretan tersebut.

Sebuah fakta yang cukup mengejutkan dibalik aktifitas pemotretan foto model yang kebanyakan orang melihat hanya dari hasil akhir karya foto yang bagus sehingga muncul anggapan harmonisnya hubungan fotografer dan modelnya.

Sebuah survey dilakukan The Model Alliance pada awal tahun 2012. Model Alliance mengirimkan sebuah survei via online kepada 241 model, dan hanya 85 dari mereka yang merespons. Namun, hal tersebut tentunya tetap saja berarti. Banyak model, terutama di usia muda, mengalami gangguan makan serta depresi. 68\% dari model menderita depresi dan gelisah berlebih, sedangkan 50\% mengaku menggunakan kokain (sejenis narkoba) saat bekerja. Masih ada lagi, 30\% dari mereka merasa disentuh secara tidak pantas (berlebihpelecehan) dalam pemotretan, kemudian 28\% mengatakan kalau mereka dipaksa berhubungan seksual oleh seseorang di tempat kerja. Ini menjadi hal yang sangat memprihatinkan karena kebanyakan dari mereka masih di bawah usia 18 tahun (ceritamu.com, 2012).

Adapun alasan lain yang menguatkan peneliti melakukan penelitian ini adalah karena pernyataan dari salah seorang informan model bernama Dea (bukan nama sebenarnya) yang menceritakan pengalamannya selama menjadi model:

\footnotetext{
"Ya, dalam proses pemotretan itu ngga semuanya sama. Aku bisabilang gini karena udah liat dari beberapa pengalaman, kalo fotografernya berbeda lagi, ya kita tentu perlu adaptasi lagi. Di sini sih yang susah, kalo modelnya yang nggak sabaran, atau sebaliknya, seringkali terjadi masalah. Jadi, kalo ditanya soal hambatan, wah jelas pasti ada."
} 
Sebagaimana telah disinggung di atas bahwa inilah yang menarik untuk diteliti. Interaksi antara fotografer dan model tidak selalu berjalan mulus. Oleh karena itu, peneliti tertarik untuk melakukan penelitian ini. Dengan adanya komunikasiyangbaik antara fotograferdan model fotonya menjadi hal penting, guna mendapat kan kesepahaman mengenai konsep pemotretan dan hasil yang ingin di capai dalam sebuah pemotretan, selain mengurangi kesalahpahaman dan hal-hal yang akan merugikan keduanya.

\section{Fotografer dalam ilmu komunikasi}

Sebagai salah satu profesi yang peneliti ambil adalah fotografer. Dikenal sebagai profesi yang bekerja di balik foto untuk mengabadikan setiap momen yang terjadi di lingkungan kita. Walaupun setiap orang bisa menghasilkan foto menggunakan kameranya. Akan tetapi, kebanyakan orang akan lebih percaya memberikan tanggung jawab mengabadikan momen hidupnya kepada seorang fotografer, mengingat terkadang moment yang akan diabadikan adalah sebuah moment penting yang mungkin tidak dapat di ulang kembali.

"Fotografer profesional menjadikan fotografi sebagai profesi, pekerjaan untuk mencari uang. Biasanya fotografer profesional membekali diri dengan keahlian fotografi yang memadai" (Darmawan, 2009).

Baik tidaknya sebuah foto bisa kita lihat dari salah satu sudut pandang, yaitu tersampaikannya pesan, ide, atau gagasan yang dimaksud oleh fotografer, yang disampaikannya dalam bentuk sebuah karya foto. Dan seorang fotografer kemudian dinilai baik, atau berhasil dari segi pesan, ide, atau gagasannya yang dituangkannya dalam sebuah karya foto yang disampaikan dapat dimengerti dan difahami oleh orang lain yang melihat atau menikmati karya foto tersebut..
Sebagai contoh, ketika fotografer mengabadikan sebuah momen yang menggambarkan sebuah sedih melalui kamera dan menghasilkan sebuah karya foto, selanjutnya orang yang melihat karya foto tersebut bisa merasakan kesedihan dari karya foto tersebut, maka karya foto yang di buat fotografer tersebut itu dinilai baik karena kita bisa menangkap pesan, ide dan gagasan dari fotografer tentang suasana sedih yang di sajikan dalam karya foto yang dihasilkannya.

Karya foto yang baik tidak lepas dari konsep, ide, dan sikap baik dari seorang fotografer. Terlepas dari persiapan yang menunjang dan peralatan fotografi yang baik, sikap baik seorang fotografer sangatlah penting. Setiap karya foto yang baik itu harus ada suatu proses sikap berfotografi yang baik pula dan itu menjadi tanggung jawab pada si fotografernya. Mungkin terdengar sederhana sekali. Tapi makin direnungi, fakta ini makin terasa kuat. Seseorang tidak mungkin menghasilkan foto yang baik, yang berkesan, apalagi yang berwatak, bila tidak dilandasi sikap mental berfotografi yang baik dan tepat.

Dalam rangka menghasilkan sebuah mahakarya yang disebut foto, fotografer perlu melakukan eksplorasi terhadap karya seperti apa yang akan dia buat, melalui ide dan konsep sang fotografer, sikap bagaimana yang akan ia berikan terhadap karyanya tadi, sehingga pesan yang dimaksudkan bisa tersampaikan kepada orang lain yang melihat fotonya. Foto tadi dihasilkan melalui proses aktivitas fotografi; dimulai lahirnya sebuah konsep atau ide, buah hasil dari pemikiran, pengalaman, serta teknik yang dimiliki fotografer tersebut.

Menggunakan kamera serta peralatan lainnya yang menunjang, aktivitas memotret dalam hal ini fotografi bisa dilakukan oleh siapa saja yang memiliki kesempatan, namun untuk seorang fotografer dapat berfotografi 
dengan baiklah yang belum tentu dapat dilakukan oleh semua orang. Dengan melihat berbagai hasil karya fotografer di sekitar kita, ada yang menyampaikan pesan dengan gambar hasil karyanya secara langsung, persuasif, sugertif, bahkan ada yang menyampaikan tanda tanya bagi publiknya. Tentu saja ini dipengaruhi oleh konsep dasar, art director, strata sosial publik, bahkan fotografernya sendiri. Hingga akhirnya konsep diri yang di dalamnya terdapat pengetahuan, pengharapan, serta nilai yang menjadi aspeknya terbentuknya mental berfotografi bagi seorang fotografer.

Fotografer atau juru foto (photographer) adalah:

"Orang-orang yang membuat gambar dengan cara menangkap cahaya dari subjek gambar dengan kamera maupun peralatan fotografi lainnya, dan umumnya memikirkan seni dan teknik untuk menghasilkan foto yang lebih bagus serta berusaha mengembangkan ilmunya. Banyak fotografer yang menggunakan kamera dan alatnya sebagai pekerjaan untuk mencari penghasilan." (Indonesia, 2000)

Fotografi sering disebut sebagai aktivitas ekspresi diri dari sorang seniman foto. Telah hadir lebih dari 1,5 abad lalu, dan telah menjadi sebuah inovasi tiada henti sejalan dengan perkembangan teknologi dan ilmu pengetahuan yang mendukungnya.

Fotografi berasal dari bahasa Yunani, terdiri dari dua kata: photos berarti cahaya, dan graphos artinya melukis, menggambar. Secara harfiah Fotografi (photography) mengandung arti melukis atau menggambar dengan cahaya. Seni atau proses penghasilan gambar dengan cahaya pada film atau permukaan yang dipekakan. Fotografi merupakan aktivitas dimulai terbentuknya konsep atau ide foto, kemudian aktifitas memotret itu sendiri hingga hasil karya fotonya, menjadi fenomena yang dewasa ini hadir di mana-mana (omnipresence) bahkan di setiap elemen kehidupan masyarakat yang memasuki era informasi.

\section{Hambatan-hambatan komunikasi}

Meskipun informasi yang disampaikan sebenarnya mudah dimengerti, tetapi ternyata komunikasi yang terjalin tersebut tidak sesuai dengan apa yang diharapkan atau diinginkan. Hal ini dapat terjadi sebab di dalam pelaksanaan komunikasi banyak sekali hambatan yang mungkin timbul.

Penurunan isi dan mutu pesan dapat terjadi pada setiap tahap dalam proses komunikasi, mulai dari perumusan konsep gagasan di dalam kata-kata sampai saat pemanfaatan yang diterima. Lebih lanjut hambatan-hambatan ini secara umum dapat di klasifikasikan menjadi tiga menurut (Arni, 2009), yaitu: (1) Hambatan Pribadi, yakni gangguan komunikasi yang timbul dari emisi, nilai dan kebiasaan menyimak yang tidak baik. Hambatan pribadi seringkali mencakup jarak psikologi di antaranya orang-orang yang serupa dengan jarak fisik sesungguhnya. (2) Hambatan Fisik, yakni gangguan komunikasi yang terjadi di lingkungan tempat berlangsungnya komunikasi. (3) Hambatan Semantik, yakni hambatan ini berasal dari keterbatasan simbol-simbol itu sendiri. Ada beberapa karakteristik dari bahasa yang menyebabkan proses decoding dalam bahasa semakin sulit antara lain: (1) Bahasa itu statis sedangkan realitasnya dinamis. (2) Bahasa itu terbatas sedangkan realitasnya tidak terbatas. (3) Bahasa itu bersifat abstrak.

Selain tahap-tahap dan akibat adanya hambatan dalam komunikasi, maka umpan balik sangat diperlukan. Umpan balik merupakan arah yang utama bagi pengirim pesan untuk 
memantau apakah pesannya dimengerti dan dimanfaatkan oleh penerima sesuai dengan harapannya.

Berdasarkan uraian di atas dapat disimpulkan bahwa komunikasi sangat penting dalam kehidupan sehari-hari. Tanpa komunikasi atau kurangnya komunikasi akan membuat pekerjaan menjadi kurang maksimal dan akan terjadinya kesalahpahaman dalam menangkap suatu informasi.

\section{Proses komunikasi}

Proses komunikasi pada hakikatnya adalah proses penyampaian lambang yang berarti oleh seseorang kepada orang lain, baik dengan maksud agar mengerti maupun agar berubah perilakunya.

Suatu komunikasi dapat dikatakan efektif atau berhasil apabila di antara penyebar pesan (komunikator) dan penerima pesan (komunikan) terdapat satu pengertian yang sama mengenai isi pesan. Isi pesan disampaikan oleh penyebar melalui lambang yang berarti. Lambang-lambang itu dapat dikatakan sebagai "titian" atau "kendaraan" untuk membawa pesan kepada si penerima pesan.

Terlihat bahwa dalam komunikasi terdapat tiga unsur penting, yaitu : komunikator, pesan, dan komunikan. Komunikator adalah sumber yang memiliki ide atau gagasan mengenai sesuatu yang akan disampaikan kepada komunikan. Pesan adalah gagasan yang berupa lambang-lambang yang berarti dan disampaikan oleh komunikator kepada komunikan, sedangkan komunikan adalah orang atau badan yang menerima pesan. Kegiatan komunikasi tidak akan berjalan secara efektif apabila tidak didukung dengan ketiga faktor tersebut yaitu komunikator, pesan, dan komunikan.

Dengan demikian, agar komunikasi berlangsung secara efektif maka kita harus memerhatikan faktor- faktor tersebut, yaitu komunikator, pesan, dan komunikan. Faktor lain yang penting dalam suatu proses komunikasi adalah umpan balik atau efek. Umpan balik memegang peranan penting dalam komunikasi sebab ia menentukan berlanjutnya komunikasi atau berhentinya komunikasi yang dilancarkan oleh komunikator . Dengan kata lain, umpan balik menentukan sukses atau tidaknya sebuah proses komunikasi dilangsungkan.

(1) Kredibilitas merupakan salah satu faktor dari komunikator yang mempunyai peranan penting agar pesan yang dikomunikasikan dapat berjalan lancar dan dapat diterima atau dipahami komunikan. Menurut Rakhmat (2007) dalam bukunya Psikologi Komunikasi, kredibilitas adalah seperangkat lambang bermakna yang disampaikan oleh komunikator.

(2) Pesan merupakan seperangkat lambang bermakna yang disampaikan oleh komunikator (Effendy, 2000). Dalam menyampaikan pesan secara lisan, faktor pemilihan kata-kata merupakan hal yang sangat penting agar sasaran yang dituju mengerti dengan maksud yang disampaikan. Pesanharusdirancangdandisampaikan sedemikian rupa sehingga dapat menarik perhatian komunikan. Pesan harus membangkitkan kebutuhan pribadi komunikan dan menyarankan beberapa cara untuk memeroleh kebutuhan tersebut. Pesan harus menyarankan suatu jalan untuk memeroleh kebutuhan tadi yang layak bagi situasi kelompok di mana komunikan berada pada saat ia digerakkan untuk memberikan pendapat dalam mencapai tujuan (Rakhmat, 2007).

Berdasarkan pesan-pesan tersebut, maka seorang komunikator harus dapat menyampaikan pesan dengan baik, misalnya bagaimana kejelasan isi 
pesan tersebut, bahasa yang digunakan apakah mudah dipahami, isi pesan tersebut apakah sesuai dengan kebutuhan masyarakat.

\section{Teori interaksi simbolik}

Esensi dari interaksi simbolik menekankan pada suatu aktivitas yang merupakan ciri khas manusia, yakni komunikasi atau pertukaran simbol yang diberi makna (Mulyana, 2005). Banyak ahli di belakang perspektif ini yang mengatakan bahwa individu sebagai manusia merupakan hal yang paling penting. Mereka mengatakan bahwa individu adalah objek yang bisa secara langsung ditelaah dan dianalisis melalui interaksinya dengan individu yang lain. Mind, Self and Society merupakan judul buku yang menjadi rujukan utama teori interaksi simbolik, merefleksikan tiga konsep utama dari teori. Definisi singkat dari ke tiga ide dasar dari interaksi simbolik, yaitu:

(1) Pikiran (Mind). Pikiran adalah kemampuan untuk menggunakan simbol yang mempunyai makna sosial yang sama, dimana tiap individu harus mengembangkan pikiranmereka melalui interaksi dengan individu lain (West, 2008). Simbol yang bermakna adalah tindakan verbal berupa bahasa yang merupakan mekanisme utama interaksi manusia. Penggunaan bahasa atau isyarat simbolik oleh manusia dalam interaksi sosial mereka pada gilirannya memunculkan pikiran (mind) yang memungkinkannya menginternalisasi masyarakat. Jadi menurut Mead, pikiran mensyaratkan adanya masyarakat; dengan kata lain masyarakat harus lebih dulu ada sebelum adanya pikiran (Mulyana, 2003). Dengan demikian pikiran adalah bagian integral dari dari proses sosial, bukan sebaliknya proses sosial adalah produk pikiran. Menurut Mead, lewat berfikir yang terutama ditandai degan kesadaran,manusia mampu mencegah tindakannya sendiri untuk sementara, menunda reaksinya terhadap suatu stimulus (Mulyana, 2003). Manusia juga mampu mengambil suatu stimulus di antara sekian banyak stimulus alih-alih bereaksi terhadap stimulus yang pertama dan yang paling kuat. Manusia pun mampu pula memilih suatu tindakan di antara berbagai tindakan yang direncanakan atau dibayangkan.

(2) Diri (Self). Diri adalah kemampuan untuk merefleksikan diri sendiri dari sudut pandang atau pendapat orang lain. Di sini diri tidak dapat dilihat dari dalam diri seseorang melalui introspeksi diri. Bagi Mead, diri hanya bisa berkembang melalui kemampuan pengambilan peran, yaitu membayangkan diri dari pandangan orang lain (West, 2008). Konsep melihat diri dari pandangan orang lain sebenarnya sebuah konsep yang pernah disampaikan oleh Charles Cooley pada 1912. Konsepnya adalah the looking glass self yaitu kemampuan melihat diri melalui pantulan dari pandangan orang lain. Cooley meyakini bahwa ada tida prinsip perkembangan sehubungan dengan the looking glass self, yaitu (1) membayangkan penampilan kita di hadapan orang lain, (2) membayangkan penilaian mereka terhadap penampilan kita, dan (3) merasa sakit hati atau bangga karena perasaan diri.

(3) Masyarakat (Society) adalah jejaring hubungan sosial yang diciptakan, dibangun, dan dikonstruksikan oleh tiap individu di tengah masyarakat, dan tiap individu tersebut terlibat dalam perilaku yang mereka pilih secara aktif dan sukarela, yang pada akhirnya mengantarkan manusia dalam proses pengambilan peran di 
Wiki Angga Wiksana. Studi Deskriptif Kualitatif tentang Hambatan Komunikasi...

tengah masyarakatnya.

\section{METODOLOGI}

Pendekatan penelitian yang digunakan dalam penelitian ini adalah paradigma konstruktivis dengan metode deskriptif. Metode deskriptif adalah suatu metode dalam meneliti status sekelompok manusia, suatu obyek, suatu set kondisi, suatu sistem pemikiran, ataupun suatu kelas peristiwa pada masa sekarang.

Tujuan dari penelitian deskriptif ini adalah untuk membuat deskipsi, gambaran, atau lukisan secara sistematis, faktual dan akurat mengenai fakta-fakta, sifat-sifat serta hubungan antarfenomena yang diselidiki.

"Metodologi adalah proses, prinsip, dan prosedur yang kita gunakan untuk mendekati problem dan mencari jawaban" (Mulyana, 2003). Menurut Sugiyono (Sugiyono, 2007), metode penelitian kualitatif merupakan suatu penelitian yang digunakan untuk meneliti pada objek yang alamiah di mana peneliti adalah sebagai instrumen kunci, teknik pengumpulan data dilakukan secara gabungan, analisis data bersifat induktif, dan hasil penelitian kualitatif lebih menekankan makna daripada generalisasi.

Penelitian kualitatif bertujuan mempertahankan bentuk dan isi perilaku manusia dan menganalisis kualitaskualitasnya, alih-alih mengubahnya menjadi entitas-entitas kuantitatif (Mulyana, 2003).

Metode yang peneliti gunakan dalam penelitian ini adalah dengan menggunakan metode penelitian deskriptif dengan analisis data kualitatif. Disebut sebagai metode deskriptif karena penelitian ini tidak menggunakan hipotesis dan variabel, melainkan hanya menggambarkan dan menganalisis kejadian yang ada tanpa perlakuan khusus atas objek-objek yang diteliti.
Mengenai tipe deskriptif, Jalaluddin Rakhmat dalam buku Metode Penelitian Komunikasi menjelaskan bahwa "Penelitian deskriptif hanyalah memaparkan situasi atau peristiwa. Penelitian ini tidak mencari atau menjelaskan hubungan, tidak menguji hipotesis atau membuat prediksi". (Rakhmat, 2002)

Lebih lanjut Rakhmat menjelaskan, "Ciri lain metode deskriptif ialah titik berat pada observasi dan suasana alamiah (naturalisasi setting). Peneliti bertindak sebagai pengamat. Ia hanya membuat kategori pelaku, mengamati gejala, dan mencatatnya dalam buku observasi (Rakhmat, 2002).

\section{Teknik pengumpulan data}

Teknik pengumpulan data dalam penelitian kualitatif adalah dengan melakukan observasi, wawancara mendalam, dan studi dokumentasi.

(1) Observasi yang dilakukan dalam penelitian ini adalah pengamatan. Pengamatan dilakukan dengan cara participant observation, terhadap objekyangditelitiyaituyangberkaitan dengan hambatan komunikasi dalam interaksi fotografer dan model pada proses pemotretan.

(2) Wawancara yang penulis lakukan dalam penelitian dimaksudkan untuk mengetahui pandangan, kejadian, kegiatan, pendapat, perasaan dari nara sumber (subjek matter expert). Wawancara dilakukan yaitu untuk mengetahui mengenai dengan hambatan komunikasi dalam interaksi fotografer dan model pada proses pemotretan. Penggunaan teknik ini sangat penting bagi penelitian kualitatif, terutama untuk melengkapi data dan upaya memperoleh data yang akurat dan sumber data yang tepat.

(3) Dalam penelitian ini, penulis juga melakukan studi dokumentasi 
tentang hambatan komunikasi dalam interaksi fotografer dan model pada proses pemotretan. Studi dokumentasi yang dilakukan dalam penelitian ini adalah dengan menelusuri data dari beberapa sumber yang terkait dengan penelitian ini. Misalnya, literatur tentang fotografer, model, dan interaksi simbolik dari bukubuku ilmu komunikasi maupun dari penelitian terdahulu yang serupa.

(4) Dalam penelitian ini, informan yang dipilih peneliti adalah seorang fotografer dan dua model profesional. Teknik penentuan informan dalam penelitian kualitatif ini adalah purposive sampling (teknik sampel bertujuan) yaitu sampel diambil dengan melalui pertimbangan tertentu sesuai dengan tujuan penelitian.

\section{TEMUAN PENELITIAN}

Dalam bagian ini, penulis ingin mendeskripsikan tentang hambatan komunikasi antara interaksi fotografer dan model dalam proses pemotretan. Berdasarkan hasil wawancara dan observasi yang telah dilakukan, penulis dapat menghasilkan temuan baru yang mampu memperkaya penelitian ini.

\section{Hambatan psikologis}

Dea (bukan nama sebenarnya), informan penelitian yang bekerja sebagai model profesional ini menceritakan tentang hambatan komunikasi yang selama ini dialaminya dalam proses pemotretan oleh fotografer.

Dea menyampaikan bahwa proses komunikasi yang dialaminya dalam setiap pemotretan sangat beragam karena setiap fotografer memiliki gaya dan cara yang berbeda-beda. Hal ini berarti Dea sebagai seorang model harus menyesuaikan diri dan beradaptasi dengan karakter fotografer yang berbeda tersebut. Ketika Dea melakukan pemotretan pertama kalinya dengan fotografer yang baru bekerjasama dengannya, Dea merasa harus mengikuti proses adaptasi itu sampai ia merasa dapat memahami apa yang diinginkan fotografernya. Artinya, Dea dan juga fotografer tersebut harus melakukan adaptasi agar proses pemotretan berjalan lancar. Di sinilah terjadi yang disebut dengan hambatan psikologis.

Dea juga menceritakan bahwa dalam para model juga sering mengalami grogi jika fotografernya adalah fotografer yang handal dan sudah terkenal. Hal ini menjadi sebuah tekanan dan menjadi sebuah tantangan baru bagi para model agar mampu menghasilkan gaya dan ekspresi yang maksimal sesuai dengan harapan fotografernya.

Hal yang hampir sama juga disampaikan oleh informan fotografer, Budi (bukan nama sebenarnya). Ternyata, fotografer juga mengalami hambatan psikologis, apalagi jika dia sedang memotret model yang dianggap susah diarahkan sesuai dengan konsep foto yang fotografer inginkan, atau sulit untuk mewujudkan konsep, ide atau gagasan foto yang diinginkan fotografer. Hal inilah yang dianggap sebagai pemicu berubahnya suasana emosi menjadi tidak stabil, misalnya perasaan kesal dengan keadaan. Ini tidak jarang juga dialami oleh para fotografer. Apalagi jika fotografer dan model tersebut telah lelah melakukan sebuah sesi pemotretan yang panjang dan memakan waktu seharian tetapi belum mendapatkan hasil foto yang sesuai dengan konsep foto yang diinginkan. Hal seperti ini tidak jarang dapat membuat mereka menyerah dan menyelesaikan sesi foto saat itu juga, dan kemudian jika dirasa suasana emosi sudah mulai membaik merekan baru akan memulai kempali aktifitas sesi pemotretannya.

Dewi (bukan nama sebenarnya), model profesional ini juga mengaku mengalami hambatan yang sama, yaitu hambatan psikologis. Dewi menceritakan 
bahwa dia juga sering mengalami perasaan kecewa jika hasil foto yang diambil oleh fotografernya tidak sesuai dengan apa konsep yang sebelumnya ia harapkan. Dalam situasi yang lain, Dewi juga bercerita jika pernah melakukan sebuah sesi pemotretan dengan fotografer yang penampilannya menakutkannya, dan kemudian hal ini yang membuat suasana sesi pemotretan itu menjadi tegang dan membuatnya merasa tidak nyaman. Jika ini terjadi, dapat dipastikan hasil foto yang didapatkan akan meleset dari konsep yang diharapkan tidak akan tercapai. Pada intinya, faktor psikologis yang dirasakan oleh model dan fotografer yang dialami pada saat sesi pemotretan akan mempengaruhi hasil akhir dari sesi pemotretan tersebut. Hambatan psikologis menjadi salah satu penghambat dari proses komunikasi yang terjadi antara fotografer dan model dalam sebuah sesi pemotretan.

\section{Hambatan semantik}

Para informan dalam penelitian ini, menyampaikan hambatan lain yang dialaminya selama proses pemotretan. Baik fotografer maupun modelnya, mereka menuturkan adanya hambatan semantik yang dirasakannya selama sesi pemotretan.

Sebagaimana telah dijelaskan dalam bagian pendahuluan tentang hambatan semantik, hambatan ini berasal dari keterbatasan simbol-simbol itu sendiri. Ada beberapa karakteristik dari bahasa yang menyebabkan proses decoding dalam bahasa semakin sulit, antara lain, bahasa itu statis sedangkan realitasnya dinamis, hal ini terlihat dari penuturan Dewi dan Dea sebagai model yang mengalami langsung hambatan semantik dalam proses pemotretan. Ketika fotografer mengarahkan gaya atau memberikan penjelasan, kadang-kadang mereka sebagai model tidak paham yang diinginkan fotografer seperti apa. Padahal mereka sebagai model telah berusaha mengikuti arahan fotografer.

Dalam hal ini, penulis melihat bahwa bahasa itu bersifat statis, ketika fotografer menyampaikan pesan secara verbal menggunakan bahasa, seringkali juga masih belum mudah untuk dimengerti oleh para model sebagai komunikan. Di sinilah terjadi hambatan semantik.

Bahasa itu terbatas sedangkan realitasnya tidak terbatas, dalam penelitian ini, penulis melihat keterbatasan bahasa menjadi hambatan semantik yang dirasakan oleh model dan fotografer sebagai informan penelitian ini.

Jika dikaji dari aspek bahasa, penulis bisa merasakan apa yang dialami oleh fotografer dan model tersebut. Bahasa itu memang terbatas, jadi ketika fotografer memberikan instruksi, arahan, atau gaya, seringkali tidak dipahami oleh modelnya. Padahal realitasnya sendiri tidak terbatas.

Bahasa itu bersifat abstrak, hal ini bisa dilihat dari interaksi fotografer dan model pada saat melakukan proses pemotretan. Ketika mereka saling berinteraksi, ada kalanya juga pesan verbal tersebut tidak dimengerti. Fotografer dan model tersebut mengaku telah berusaha saling memahami yang diinginkan, tetapi karena bahasa bersifat abstrak inilah, terjadi pula masalah teknis atau kesalahpahaman antara fotografer dan model tersebut.

\section{Hambatan pengetahuan}

Selain kedua hambatan di atas, penulis juga menemukan adanya hambatan pengetahuan yang terjadi dalam interaksi fotografer dan model dalam proses pemotretan. Hal ini terlihat jelas dengan penuturan dari Dewi sebagai model, yang menceritakan bahwa dia kadang-kadang tidak memahami yang dimaksud oleh fotografernya, jika hal itu berkaitan dengan produk yang baru atau hal-hal yang baru bagi Dewi. Begitu pun 
halnya dengan fotografer, jika bertemu dengan model yang baru, latar belakang pendidikan dan budayanya juga berbeda, ini juga seringkali menghambat proses pemotretan. Fotografer perlu beradaptasi lagi dengan kondisi modelnya. Hal ini berarti hambatan pengetahuan juga bisa terjadi bagi fotografer dan model dalam interaksi yang mereka lakukan dalam sesi pemotretan.

\section{PEMBAHASAN}

Teori interaksi simbolik menekankan pada hubungan antara simbol dan interaksi. Inti dari pandangan pendekatan ini adalah individu (Q-Anees, 2007). Banyak ahli di belakang perspektif ini yang mengatakan bahwa individu merupakan hal yang paling penting dalam konsep sosiologi. Mereka mengatakan bahwa individu adalah objek yang bisa secara langsung ditelaah dan dianalisis melalui interaksinya dengan individu yang lain.

Menurut Ralph Larossa dan Donald C. Reitzes (1993) dalam (West, 2008), interaksi simbolik pada intinya menjelaskan tentang kerangka referensi untuk memahami bagaimana manusia, bersama dengan orang lain, menciptakan dunia simbolik dan bagaimana cara dunia membentuk perilaku manusia.

Dadi Ahmadi dalam artikelnya juga menjelaskan tentang konsep interaksi dalam teori interaksi simbolik :

Manusia pada hakikatnya adalah mahluk yang berinteraksi. Bahkan, interaksi itu tidak hanya ekslusif antarmanusia, melainkan inklusif dengan seluruh mikrokosmos, termasuk interaksi manusia dengan seluruh alam ciptaan. Singkatnya, manusia selalu mengadakan interaksi. Setiap interaksi mutlak membutukan sarana tertentu. Sarana menjadi medium simbolisasi dari apa yang dimaksudkan dalam sebuah interakasi (Ahmadi, 2008).
Teori ini relevan dengan penelitian yang penulis lakukan. Penulis melihat jika teori interaksi simbolik ini menekankan pada hubungan antara simbol dan interaksi, maka dalam penelitian ini, simbol dan interaksi tersebut terjadi pada fotografer dan model yang berinteraksi dalam sesi pemotretan. Dimana sebuah sesi pemotretan, interaksi diantara fotografer dan modelnya menjadi penting karena ide, konsep dan gagasan untuk menciptakan sebuah karya foto disampaikan melalui simbol simbol yang seharusnya dapat dipahami, di menerti dan di persepsi secara sama anatara fotografer dan modelnya, sehingga konsep dan tujuan dibuatnya karya foto tersebut dapat tercapai, dimana seorang fotografer dapat menyampaikan pesan yang ia sanpaikan melalui model dengan karya foto yang tercipta.

Interaksi simbolik ada karena ide-ide dasar dalam membentuk makna yang berasal dari pikiran manusia (mind) mengenai diri (self), dan hubungannya di tengah interaksi sosial, dan tujuan bertujuan akhir untuk memediasi, serta menginterpretasi makna di tengah masyarakat (society) dimana individu tersebut menetap. Dalam penelitian ini, terlihat jelas ide dasar dalam membentuk makna yang berasal dari pikiran manusia itu adalah fotografer dan model tersebut (mind). Keduanya berinteraksi mengenai diri mereka, mereka saling menyampaikan pesan baik secara verbal maupun nonverbal (self). Hal ini bertujuan untuk menginterpretasi makna dari dari karya foto yang dihasilkan dari sebuah sesi pemotretan yang mereka lakukan yaitu menghasilkan karya foto yang maksimal sesuai dengan yang diharapkan, tentunya hasil karya foto tersebut dapat disukai dan dimengerti isi pesannya oleh masyarakat (society).

Seperti yang dicatat oleh Douglas (1970) dalam Ardianto (Q-Anees, 2007), Makna itu berasal dari interaksi, dan tidak 
Wiki Angga Wiksana. Studi Deskriptif Kualitatif tentang Hambatan Komunikasi...

ada cara lain untuk membentuk makna, selain dengan membangun hubungan dengan individu lain melalui interaksi.

\section{SIMPULAN}

Berdasarkan hasil penelitian yang telah dilakukan tentang hambatan komunikasi dalam interaksi fotografer dan foto model dalam proses pembuatan karya foto, dapat disimpulkan bahwa dalam menampilkan sebuah karya foto ternyata tidak mudah. Dalam sebuah sesi pemotretan terjadi interaksi antara fotografer dan model, dimana keduanya berusaha untuk saling memahami keinginan masing masing untuk menyajikan sebuah karya foto yang sesuai denga keinginan masing masing tersebut, meskipun dalam pelaksanaannya terkendala akan hambatan hambatan yang terjadi secara bervariasi, mulai dari hambatan psikologis, hambatan semantik, dan hambatan pengetahuan. Pada prinsipnya, hambatan komunikasi inilah yang terjadi antara fotografer dan model dalam sesi pemotretan.

\section{DAFTAR PUSTAKA}

Ahmadi, D. (2008). Interaksi Simbolik, Sebuah Pendekatan Penelitian dan Teori. Mediator, 2, 50-62.
Arni, M. (2009). Komunikasi Massa. Jakarta: Bumi Aksara Basu Swastha.

Darmawan, F. (2009). Dunia dalam Bingkai. Yogyakarta: Graha Ilmu.

Effendy, O. U. (2000). Ilmu Teori dan Filsafat Komunikasi. Bandung: PT Citra Aditya Bakti.

Indonesia, T. P. (2000). Kamus Besar Bahasa Indonesia. Jakarta: Pusat Pembinaan dan Pengembangan Bahasa.

Mulyana, D. (2005). Pengantar Ilmu Komunikasi. Bandung: PT Remaja Rosda Karya.

Mulyana, D. (2003). Metode Penelitian Komunikasi. Bandung: PT Remaja Rosda Karya.

Q-Anees, E. A. (2007). Filsafat Ilmu Komunikasi. Bandung: Simbiosa Rekatama Media.

Rakhmat, J. (2007). Psikologi Komunikasi. Bandung: PT Remaja Rosda Karya.

Rakhmat, J. (2002). Metode Penelitian Komunikasi. Bandung: PT Remaja Rosda Karya.

Sugiyono. (2007). Metode Penelitian Kuantitatif, Kualitatif, dan $R \& D$. Bandung: Alfabeta.

West, R. \&. (2008). Pengantar Teori Komunikasi: Analisis dan Aplikasi. Jakarta: Salemba Humanika. 
